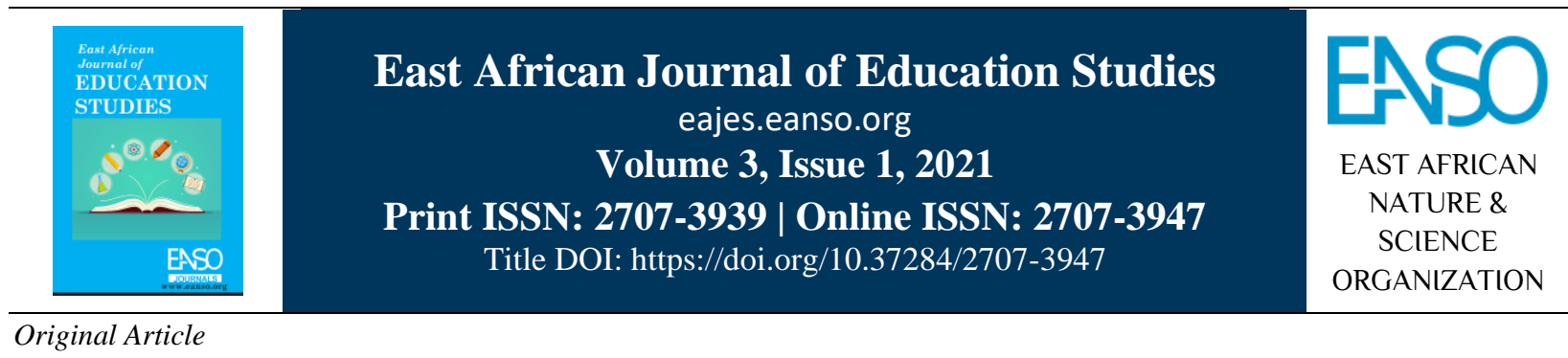

\title{
An Exploratory Study of Students' Indiscipline at Islamic University in Uganda
}

\author{
Dr. Amina Hassan ${ }^{1}$ \\ ${ }^{1}$ Islamic University in Uganda, P. O. Box 2555, Mbale, Uganda. \\ *ORCID: https://orcid.org/0000-0002-1802-1075; Author for Correspondence Email: hamina.hassan229@ gmail.com.
}

Article DOI: https://doi.org/10.37284/eajes.3.1.326

\section{Date Published: ABSTRACT}

12 May 2021 The study explored the common students' indiscipline at Islamic University in Uganda. The study was quantitative and a cross-sectional survey design was

Keywords: used. The population of the study was 3,486 registered students in the academic year 2019/2020. They were selected from the Faculty of Education, Faculty of

Discipline, Management Studies, Faculty of Law, Faculty of Social Sciences, and Faculty Explore, of Science. A sample of 265 respondents was selected for the study using Common, proportionate and random sampling. The mean score was computed to analyse Types, the data. To conclude, the point range of the arithmetic mean was considered. Islamic University, The study found that the common indiscipline among learners in IUIU included
Uganda. The disrespect to teachers and school rules and regulations, theft, and irregular attendance. The study recommended IUIU administration improves staff remuneration to change the status of the teachers. Furthermore, the administration needs to tighten security in the university and residents need to take care of their property to avoid theft. The researcher also recommended that a study should be carried out to find out the cause of students' irregular attendance

\section{APA CITATION}

Hassan, A. (2021). An Exploratory Study of Students' Indiscipline at Islamic University in Uganda. East African Journal of Education Studies, 3(1), 87-95. https://doi.org/10.37284/eajes.3.1.326.

\section{CHICAGO CITATION}

Hassan, Amina. 2021. “An Exploratory Study of Students' Indiscipline at Islamic University in Uganda”. East African Journal of Education Studies 3 (1), 87-95. https://doi.org/10.37284/eajes.3.1.326.

\section{HARVARD CITATION}

Hassan, A. (2021) “An Exploratory Study of Students' Indiscipline at Islamic University in Uganda”, East African Journal of Education Studies, 3(1), pp. 87-95. doi: 10.37284/eajes.3.1.326.

87| This work is licensed under a Creative Commons Attribution 4.0 International License. 


\section{IEEE CITATION}

A. Hassan, “An Exploratory Study of Students' Indiscipline at Islamic University in Uganda”, EAJES, vol. 3, no. 1, pp. 87-95, May. 2021.

\section{MLA CITATION}

Hassan, Amina. "An Exploratory Study of Students' Indiscipline at Islamic University in Uganda". East African Journal of Education Studies, Vol. 3, no. 1, May. 2021, pp. 87-95, doi:10.37284/eajes.3.1.326.

\section{INTRODUCTION}

Discipline is one of the most important things in everyone's life and it is a source of happiness for everyone. Discipline is the act of living life following rules and regulations. It leads us on the right path. Student behaviour policy is the foundation for adequate education in schools (Ibenegbu, 2017); therefore, it is always necessary to analyse and investigate the causes of indiscipline (Ibenegbu, 2017). Islamic University in Uganda (IUIU) has a students' code of conduct and this code is availed to every student who joins the university. Students are expected to observe the rules and regulations in this guide to go through the university without any challenges. These rules were amended in 2007 and are categorised under general conduct rules, residential hall rules, and academic rules. Islamic University coordinator's department students rules (2007) briefly state:

All resident students shall be in residence not later than $9.00 \mathrm{pm}$. All-female students shall be on campus except where necessary. All students must report to their halls of resident on the appointed day. Female students should seek permission to go out of campus. No cooking is allowed in the rooms where students reside; however, they are allowed to cook under the cooking shade provided by the university. Concerning visitors to residents; No student shall visit students of the opposite sex in their halls of residence. All resident students shall remain in their hall of residence between 11.00 pm until dawn unless prior permission had been obtained from the warden, and extra. Students should handle university property with utmost care to avoid possible damage.

Also, no university property shall be taken out of the premises without written permission from the department concerned. As regards to code of dress and cleanliness, every student shall dress in a decent manner befitting the norms of an
Islamic institution as per the guidelines. Any student who litters his/her room or other premises of the university shall be guilty of an offense and may be liable to disciplinary action. As regards the consumption of drugs and alcohol, no student is allowed to consume such substance unless such consumption has been prescribed by a recognised medical officer approved by the university medical officer. On social function, permission to such functions should be sought from the university coordinator. Interaction between male and female members in a manner not acceptable in Islam (fuelling) is prohibited. As regards insubordination to university authority, any student who disobeys or obstructs, or interferes with any authorised university officials in the execution of his/her duties shall be guilty of an offense. Pre-marital and or extra-marital sex and pregnancies are illegal and punishable by expulsion. There are more issues highlighted to guide the learners. These rules also prescribe likely punishment to be meted to be a culprit in case he/she is convicted. Such punishment varies according to the gravity of the offense. The punishments include; warning, reprimand, disqualification, writing apology, dead year, expulsion, and any other punishment as deemed necessary by the disciplinary committee.

The guidelines also stipulate machinery for the implementation of the university rules. Any member of the university should report to the authority concerned any infringements of university rules. Breaches of university or hall rules may become the subject report to the warden, university coordinator, vice-rector, and rector and may result in the student concerned having to appear before the disciplinary sub-committee (SDC) or university disciplinary committee (DC). Where necessary, members of the administrative machinery of the university deemed can take disciplinary action against a student and report to the disciplinary sub-

$88 \mid$ This work is licensed under a Creative Commons Attribution 4.0 International License. 
committee later (Coordinator's department students' rules: 2007).

Although students are given these rules on arrival at the university, students still exhibit misconducts such as theft, pregnancy outside marriage, destroying property, insubordination, drug abuse, indecent dressing, and extra. (Minutes of SDC and DC meetings: 2016, 2017, 2018, 2019). The shocking news of IUIU expelling students was published in media and newspapers. The Daily Monitor (2018) reported that IUIU students protest suspension over sex and the Campus bee reported that IUIU expelled 40 students over fornication. It is against this background that the researcher anticipated exploring the kinds of common indiscipline among students of IUIU. The study was guided by the following research questions:

i. What are the common kinds of Indiscipline among IUIU students?

ii. Is there a significant difference in the mean of indiscipline score for males and females?

\section{LITERATURE REVIEW}

Tirgar et al. (2020) examined the causes of students' irregularities in class formation at the beginning of each semester in medical sciences universities in Iran. It was a cross-sectional study carried out in three universities; Babol, Shahid Beheshti, and Iran University of Medical Sciences on two groups of students; those who attended the first classes of the semester and those who missed. The study revealed that the reasons for students attending the first classes in the semester are the importance of specialised courses and teacher's emphasis. The reasons for those who missed included; their experience of cancellation of first lectures, failure of students to pay attention to the first lectures, and age of learners. This study focused on irregularity variables in Iran medical universities while the present study explored common types of learners' indiscipline in the Islamic University in Uganda.

Mohamed et al. (2018) determined the factors that influence students' absenteeism from calculus courses for an engineering major. The domains of the questionnaire were absenteeism, electronic media factor, family factor, class climate factor, student attitude factor, peer factor, and student activity factor. The study revealed that there was a significant relationship between student's attitude factor, student activity, and family factor towards absenteeism. Mohamed et al. (2018) studied causes of absenteeism in university technology in Malaysia, yet my study explored types of indiscipline in the Islamic University in Uganda.

Mareš (2018) studied the manifestations of students' indiscipline, especially in primary and secondary schools. The study's variables were five and included; why it is difficult to define students' indiscipline, categories of students' indiscipline, factors influencing students' indiscipline, methods used to identify students' discipline, consequences of students' indiscipline and approaches used to hand students' misbehaviour in the classroom. The study reviewed 121 foreign research published papers from 1986-2018 on studies conducted on Euro-American social-cultural studies environment. The study revealed the factors influencing students' indiscipline in the classroom comprised special characteristics of the students themselves, their classmates, teachers, the entire class, interactions between the teacher and the class; special characteristics of the respective school, school district, students' family background, educational system of the respective country and its school policies. Whereas this study looked at factors influencing students' indiscipline in a classroom, my study explored the common types of students' indiscipline in IUIU.

Mwaniki (2018) studied the causes of miss behaviour among learners in Kenyan secondary schools. The objectives of the study included the common indiscipline and their causes in Kenyan secondary schools. The findings revealed the common indiscipline as sneaking out of school compound, theft, vernacular speaking, and drug abuse. The study revealed the main causes of student indiscipline to include protective guardians, inconsistency of punishment, drug abuse, poor parental care, and peer pressure. The study recommended that the main school stakeholders should make collective efforts to study the causes of students' indiscipline to reverse the trend.

Ramchander (2017) established the contextual factors that influenced student absenteeism at the

89| This work is licensed under a Creative Commons Attribution 4.0 International License. 
Durban University of Technology (DUT), South Africa. The study was quantitative and used a crosssectional survey design. A sample of 140 students from the management department participated in the study. The study revealed that first-year students had a greater tendency to be late for the first period (08.00) than second-year or third-year students. Furthermore, the students chose to absent themselves from class to study for tests, complete assignments, or engage in group work. Most students absent themselves on the day before the test as well as the day of the test. The study recommended that there is a need to dedicate time for testing during which no lecturers are scheduled and to plan the timetable so that first-year lecturers start in the second period (09.00). Ramchander's study focused on absenteeism as a variable, while my study focuses on indiscipline as a variable.

Mwaniki, Njuguri and Kanjogu (2016) studied the influence of teacher-student relationships on students' indiscipline in public secondary schools in Naivasha sub-county, Kenya. The study concluded that the higher the level of the teacher-student relationship, the less level of indiscipline in schools. Therefore teacher-student relationship influences students' discipline in secondary schools in Naivasha Sub-County. The study recommended that schools should ensure a good relationship between learners and teachers to enable discipline among learners in the school.

Emurugat, Soi, and Wunti (2012) analysed the relationship between promotion and employee discipline in private Universities in Uganda. It involved 385 respondents from chartered and accredited universities. The study found that promotion was a significant factor in maintaining staff discipline in private universities. Emurugat et al. (2012) were concerned with staff discipline in private universities while the current is focused on common students' indiscipline in IUIU.

Hassan (2019) explored factors influencing student discipline in universities in Uganda. The study used Principal Component Analysis to extract the factors. The study extracted two factors influencing students' indiscipline and they were; political and administrative factors. The current study explored the common students' indiscipline at Islamic University in Uganda. Nakayiwa and Kangazi
(2015) explored the causes of unrest in universities in Ugandan universities. The objectives of the study were the nature of causes of strike and implications to staff and students. Their study was purely qualitative and they sampled top administration from staff and students. The study findings revealed the causes of strikes in these institutions as external influence, inadequacies, and break down of governance structures within the universities.

Ndagire (2012) examined the management of student discipline in private secondary schools in Entebbe Municipality Wakiso district in Uganda. The study objectives included finding out the forms of indiscipline, measures to manage discipline, and how these measures are implemented. Ndagire's study was on how to manage discipline at the secondary school level, while my study was to establish the common indiscipline at the university level.

Kiggundu (2009) studied discipline management and students' academic performance in the Busiro Subcounty in Wakiso district in Uganda. The constructs in the independent variable included how school rules, administering punishment, and time managing influence student performance. The study used a cross-sectional survey design. To collect data, he used interviews and questionnaires. The study was carried out in four randomly selected private schools. He found that school rules help control learners' behaviour, but they are not aware of these rules. The study further revealed that timetable is not respected hence causing indiscipline among learners. Furthermore, punishment is poorly administered leading to chaos among learners. The study recommended guidance and counselling instead of expulsion to maintain discipline among learners. He called upon the administrators to be role models to learners.

Okurut (2007) studied factors influencing students' indiscipline in selected secondary schools in Palisa District in Uganda. The independent variables included family background, laxity of administration, quality of meals, and punishment. The study found that meals were not good hence leading to students' indiscipline. Hassan (2019) and Nakayiwa and Kangazi (2015) carried their studies on Universities in Uganda. The current study was on Islamic University in Uganda. At the same time,

90| This work is licensed under a Creative Commons Attribution 4.0 International License. 
Ndagire (2012), Kigundu (2019), and Okurut (2009) based their studies on secondary schools in Uganda. Meanwhile, the other studies were done outside Uganda.

\section{METHODOLOGY}

\section{Research Design}

This study is quantitative and a cross-sectional survey design was used in the study. The population of the study included registered students of IUIU at the main campus from various faculties. They were 1,046 students from the faculty of education, 645 students from the faculty of management studies, 646 students from the faculty of law, 416 students from the faculty of social sciences, and 733 students from the faculty of science. A total population of 3,486 registered students from the specified faculties was considered for the study. (Academic registrar's office)

\section{Sample}

Proportional and random sampling was used to determine the participants in the study. Two hundred sixty-five (265) students were selected to participate in the study. Eighty (80) students from the faculty of education, 49 from the faculty of management studies, 49 from the faculty of law, 32 from the faculty of social sciences, and 55 students from the faculty of science made up the sample size. The sample was based on the ratio of the items in the questionnaire 10:1. This was recommended by Nunnally (1978) as cited in Pallant (2005).

\section{Instrument}

A 15 Item questionnaire for indiscipline was used to collect data. A Likert questionnaire scale measuring disagree (1), not sure (2), and agree (3) was used. The respondents were asked to respond to the statements on students' indiscipline to the best of Table 1: Common Types of Indiscipline among IUIU students

\begin{tabular}{llllll}
\hline & N & Min & Max & \multicolumn{2}{l}{ Mean Std. Dev. } \\
\hline Students come to school very late & 2281 & 3 & 1.36 & .656 \\
Students don't attend classes regularly & 2281 & 3 & 2.16 & .712 \\
Students lack respect & 2281 & 3 & 2.69 & .641 \\
Students don't respect teachers & 2281 & 3 & 2.50 & .587 \\
Students don't respect school rules & 2281 & 3 & 2.48 & .662
\end{tabular}

91| This work is licensed under a Creative Commons Attribution 4.0 International License. their knowledge. The validity index of the instrument was .75 and reliability was .715 . The researcher used Cronbach alpha to measure the reliability of the instrument. The validity and reliability determined the adequateness of the instrument. It was found that the instrument was adequate to collect the data.

\section{Data Collection}

The researcher distributed the questionnaires to the different faculties and collected them within one month. The questionnaires collected were sorted to find out whether all the items were answered before entering them in SPSS for analysis. The valid questionnaires were 228 .

\section{Data analysis}

To find the kinds of indiscipline among IUIU students, the researcher computed the mean of the responses. While for objective two which required the difference between the mean of indiscipline score for males and females in IUIU, the researcher used the independent t-test to calculate the difference between the mean score for males and females.

\section{FINDINGS}

Responses on Learners' Kinds of Indiscipline

The description of learners' kinds of indiscipline was based on fifteen items in the questionnaire where learners were asked to respond to the kinds of indiscipline occurring in IUIU. The major constructs from these 15 items were; respect, theft, vandalism, and attendance. The findings were presented in Table 1 below. The interpretation was based on the point range of the arithmetic mean. The range is explained as follow $0.0-0.9=$ negative, 1.0 $-1.9=$ not sure and $2.0-2.9=$ positive . 


\begin{tabular}{llllll}
\hline & N & Min & Max & \multicolumn{2}{l}{ Mean Std. Dev. } \\
\hline Students destroy library materials & 2281 & 3 & 1.70 & .699 \\
Students destroy laboratory equipment's & 2281 & 3 & 1.79 & .702 \\
Students break chairs & 2281 & 3 & 1.64 & .719 \\
Students break windows & 2281 & 3 & 1.55 & .653 \\
Students break doors & 2281 & 3 & 1.52 & .674 \\
Students steal laptops & 2281 & 3 & 2.16 & .832 \\
Students steal phones & 2281 & 3 & 2.41 & .728 \\
Students steal hostel keys & 2281 & 3 & 1.90 & .765 \\
Students steal money & 2281 & 3 & 2.25 & .778 \\
Students steal shoes & 2281 & 3 & 2.23 & .763 \\
\hline
\end{tabular}

The findings indicate that students of IUIU involve themselves in several kinds of indiscipline. As regards lack of respect, Table 1 revealed that the highest mean was 2.69 , whereby respondents agreed with the statement that learners lack respect. This is followed by a mean of 2.50 , where respondents agreed with the statement that students don't respect teachers. This is followed by a mean of 2.48 , where respondents agreed to the statement that students don't respect school rules and regulations. Hence, the study found that students lack respect overall and in particular do not respect their teachers and the school rules and regulations.

As regards theft, the highest mean was 2.41, where students agreed with the statement that students steal phones. This was followed by a mean of 2.25 , where students agreed with the statement that students steal money (Table 1). This was followed by a mean of 2.3 , where students agreed with the statement that students steal shoes. This was followed by a mean of 2.16 , whereby students agreed with the statement that students steal a laptop. Lastly, a mean of 1.90 where the students were not sure whether students steal hostel keys. Thus, the study found that students steal items like phones, money, laptop, and shoes.

The findings revealed that students were not sure whether they vandalise the institutional property. Table 1 revealed that the respondents were not sure whether students steal hostel keys with a mean of 1.9. The next mean is 1.79 , where respondents were not sure whether students destroy laboratory equipment. The next mean was 1.70 , where respondents were silent on the statement that students destroy library materials. This was followed by a mean of 1.64 , where respondents could not agree or agree with the statement that students break chairs (Table 1). The next mean was 1.55, where respondents were not sure of the statement that students break windows. This was followed by a mean of 1.52, where respondents were not sure of the statement that students break doors. Thus, the study could not come up with conclusive position on vandalism of the institutional property.

On class attendance, respondents were not sure of the statement that students come to school very late with a mean score of 1.36 . While the respondents agreed to the statement that students don't attend classes regularly with a mean score of 2.16 (Table 1). Therefore, student irregularity was indiscipline among learners at IUIU.

\section{The difference in the Mean Discipline Score for Males and Females}

An Independent Samples t-test was conducted to compare the mean of indiscipline scores for males and females. There was no significant difference in the mean for Indiscipline score for males $(M=2.17$, $S D=.301)$ and females $(M=2.22, S D=.316) ; \mathrm{t}$ (226) $=-1.10, p=.27$. The magnitude of the differences in the means was very small (eta squared $=0.005)$. 
Table 2: Independent samples test of indiscipline scores for males and females

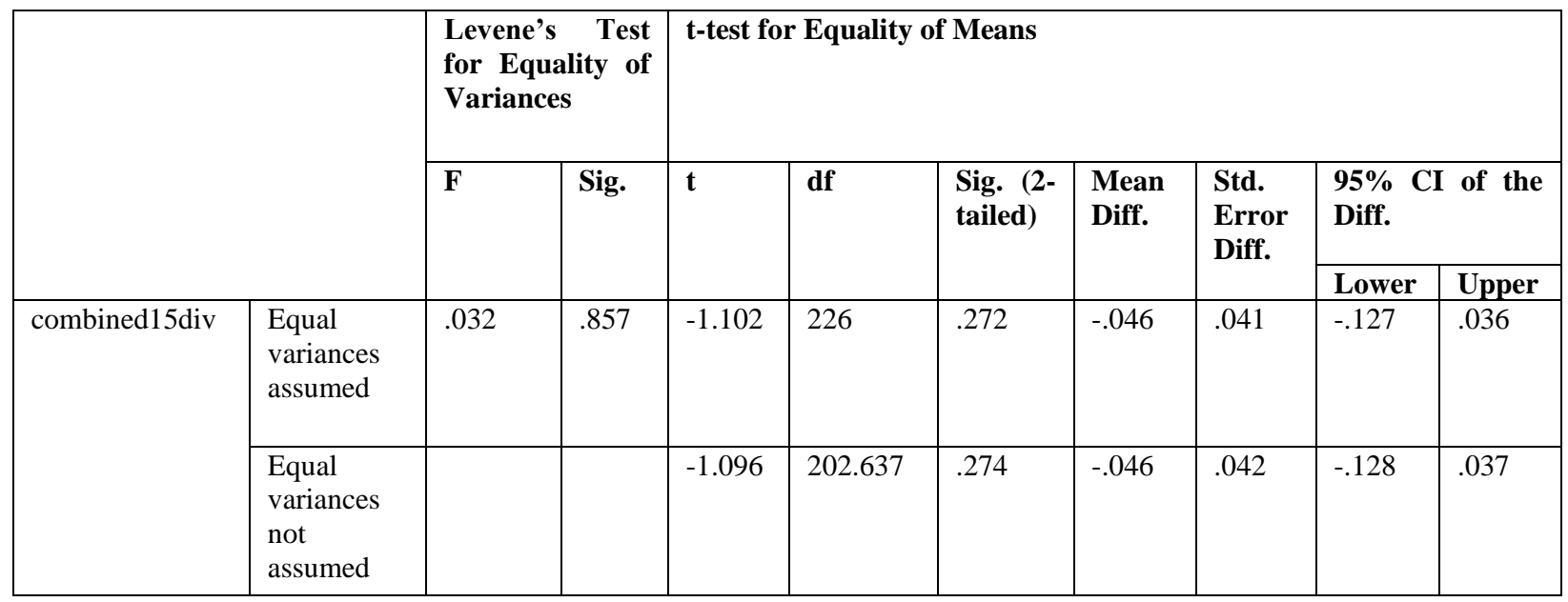

\section{Discussion of Findings}

The study revealed that lack of respect was one of the indiscipline in institutions of higher learning in Uganda. Particularly, students do not respect their teachers, do not respect school rules and regulations. Similarly, Jekayinfa (2013) observed that disobedience to teachers and school rules and regulations was among the indiscipline in the higher education system in Nigeria. Kashyap (nd.) attributes to lack of respect to teachers to the shortcomings of our present educational systems for the last 30 years which has affected the entire system. This has affected the status of the teachers. Kashyap (nd.) adds that the main reason is the low social status of teachers due to low economic conditions.

The findings further revealed that theft was another form of indiscipline in IUIU. Among the thing's students steal include; phones, money, shoes, and laptops. This study concurs with Getachew, Tekle, and Kune (2020), who found that students committed minor and major theft at Ambo University in Ethiopia. Makhaye (nd) observed that many students join university with negative family backgrounds and negative social and economic experiences. Such experiences could have left the student traumatised or even motivated to engage in criminal activity. Such factors boost the rate of crime rate that occurs on campus.
The study also revealed that student attendance was irregular. A similar study by Ramchander (2017) established the contextual factors that influenced student absenteeism at the Durban University of Technology (DUT), South Africa. The study found that the students chose to absent themselves from class to study for tests, complete assignments, or engage in group work. Many students absent themselves on the day before the test as well as the day of the test.

The third finding revealed that students were not sure whether vandalism take place on the university property. This could mean that some few do the act while others do not. The researcher believe that many students value this property because the property benefits them during their studies. Destruction of such property would make them suffer the consequence.

\section{CONCLUSIONS}

The study concluded that students' indiscipline in IUIU includes lack of respect, theft, and irregular attendance. On the other hand, students could not sure whether they involve themselves in vandalism and late coming to school. Secondly, the study found that there was no significant difference between the mean response of males and females on the indiscipline of learners. The respondents were not sure whether students were involved in vandalism of institutional property and late coming.

93 This work is licensed under a Creative Commons Attribution 4.0 International License. 


\section{RECOMMENDATIONS}

To improve respect for staff, the University management needs to improve the status of its staff. One of the critical areas is to improve the economic status of the staff. To curb down theft, management should beef up security in the university. Also, the students and staff should ensure that their property is kept properly so that no one can have access to that property. When the property is guarded, the thieves will not have access to steal. To help students respect school rules and regulations, the institution should create awareness of these rules and regulations to learners. Also, disciplinary action should be taken against the culprits. The study recommends that IUIU should carry out a study to find out why students are irregular in attendance.

\section{REFERENCES}

Daily Monitor. (2018). IUIU students protest suspension over sex. Retrieved from https://www.monitor.co.ug/uganda/news/nation al/iuiu-students-protest-suspension-over-sex1752378

Emurugat, A. I., Soi, G. S., \& Wunti, I. Y. (2017). Promotion and discipline of employees in private universities in Uganda. Integrity Journal of education and training, 1 (2), 6-16.

Getachew, A., Tekle, T., and Bayisa, K. (2020). Nature and causes of students' misbehaviour as perceived by Ambo University teachers. Journal of the social sciences, 48(2), 762-771

Hassan, A. (2019). An exploratory factor analysis for factors influencing student's indiscipline in universities in Uganda. In Amutabi, M.N. \& Henry, L. H., Global trends in Africa's Development. Nairobi, KE: Centre for democracy, research, and development (CEDRED).

Ibenegbu, G. (2017). Major causes of indiscipline in schools. Retrieved on July 222020 from https://www.legit.ng/1130027-majorindiscipline-schools.html.

Jekayinfa, A.A. (2013). Discipline and Indiscipline in Higher educational system. A paper delivered at the workshop on improved teaching and learning methods in the higher education system, organised by the Afe Babalola University, ADOEKITI. Nigeria, 9 9 $^{\text {th }} 12$ th April 2013.

Kashyap, D. (nd). Indiscipline in Educational Institution: Causes and Suggestions. Retrieved on March 52021 from https://www.yourarticlelibrary.com/educational -management/indiscipline-in-educationalinstitution-causes-and-suggestions/ 63722

Kiggundu, H. (2009). The Influence of discipline management by headteachers on students' academic performance in selected private secondary schools of Busiro County in Wakiso District. Masters' Thesis. Makerere university institutional repository. Retrieved on March 7 2021 from http://makir.mak.ac.ug/handle/10570 12278

Makhaye, M. (nd). Crimes in institutions of higher learning. Safer spaces. Retrieved on March 7 2021 from https://www.saferspaces.org.za/unde rstand/entry/crime-in-institutions-of-higherlearning\#Universitiesas'hotspots'ofcrime

Mareš, J. (2018). Students' Indiscipline in the Classroom. Pedagogická orientace, 28(4), 556598.

Mohamed, S. A., Ul-Saufie, A. Z., Ahmad, N., Ahmat, H. * Zhari, M. F. (2018). Factors influencing students' absenteeism in the university. Proceeding of the 25th National Symposium on Mathematical Sciences (SKSM25). American Institute of Physics.

Mwaniki, G. S. K., Ngunjiri, M., Kanjogu, J. (2016). Influence of teacher-student relationship on students' indiscipline in public secondary schools in Naivasha Sub County, Kenya. IORS Journal of humanities and social sciences, 21 (9), 30-37.

Mwaniki, S. (2018). Students' indiscipline: A reflection on the causes of misbehaviour among learners in Kenyan secondary schools. Global Journal of Advanced Research, 5(6), 171-177.

Nakayiwa, F. \& Kangazi, P. (2015). Staff and students unrest in Ugandan universities: Challenges and opportunities for reform. A

94| This work is licensed under a Creative Commons Attribution 4.0 International License. 
study commissioned by the Uganda vice chancellors forum September 2015.

Ndagire, B. (2012). Management of students' discipline in private secondary schools in Ntebbe Municipality Wakiso District. Masters' dissertation, Makerere University.

Okurut, G. (2007). Factors influencing students' indiscipline in selected secondary schools in Palisa District, Uganda. Masters' dissertation, Kampala international university.

Pallant, J. (2005). SPSS survival manual. Allen and Unwin: Crows West, Australia.

Ramchander, M. (2017). Contextual factors influencing student absenteeism at higher education institution in South Africa. African Education Review, 14(6), 1-14.

Tirgar, A., Mousavie Anijdan, S. H., Pouyakian, M., Javanshir, K., Alimohammadi, I., \& Aghalari, Z. (2020). The causes of students' irregularities in class formation at the beginning of each semester in medical sciences universities. Biannual Journal of Medical Education Education Development Center (edc) Babol University of Medical Sciences, 8(1), 23-31.

95| This work is licensed under a Creative Commons Attribution 4.0 International License. 